\title{
Etnograficzne mapowanie polskiej Góralszczyzny przez Wincentego Pola i innych badaczy
}

Ethnographic mapping of the Polish Highlanders' region by Wincenty Pol and other researchers

\section{Substancjalne pojmowanie ugrupowania etnograficznego}

Ėmile Durkheim i Marcel Mauss w znanym eseju o formach klasyfikacji - opublikowanym pierwotnie w „L'Annee Sociologique” (1901-1902) - za oczywistość uznali to, że naukowe klasyfikowanie rzeczy polega na zaliczaniu ich do różnych grup, które są od siebie oddzielone wyraźnymi liniami granicznymi (Durkheim, Mauss 1973: 709). Te sklasyfikowane, podzielone na gatunki i rodzaje byty, idee, zjawiska itd., pozostają ze sobą w określonych związkach, tworząc pewne układy, wyrażane przez system zhierarchizowanych pojęć. Uczeni ci słusznie zauważyli też, że taka koncepcja nie sięga w przeszłość dalej niż do Arystotelesa, który pierwszy głosił realne istnienie różnic pomiędzy gatunkami i rodzajami oraz niemożność bezpośredniego przejścia od jednego gatunku/rodzaju do drugiego. Istotnie Arystotelesowska teoria kategoryzacji - oparta na logice z zasadami tożsamości, sprzeczności i wyłączonego środka - jest podstawą, na której opiera się pogląd głoszący, że granice pomiędzy bytami, gatunkami i rodzajami mogą być jednoznacznie określone. Według Arystotelesa w podziale logicznym powinny być brane pod uwagę wyłącznie cechy rodzajowe i różnice gatunkowe. Terminy „rodzaj” i "gatunek” oznaczają człony stosunku nadrzędności i podrzędności zachodzącego między pojęciami ze względu na ich zakresy: pojęcie nadrzędne jest 
rodzajem, zaś odpowiednie pojęcie podrzędne - gatunkiem. Pośrednie ogniwa klasyfikacji przedstawiającej hierarchiczny porządek rodzajów i gatunków są zarazem rodzajami (względem wszystkich kolejnych członów podrzędnych, np. ciało względem ciała ożywionego, zwierzęcia itd.) i gatunkami (wobec wszystkich kolejnych członów nadrzędnych, np. zwierzę względem ciała ożywionego i substancji).

Stanowisko takie - można określić je „substancjalizmem” lub „esencjalizmem” - było dominujące w średniowiecznej scholastyce. Umberto Eco pisał: „Zasady greckiej logiki podpierają średniowieczną wiarę w to, że granice pomiędzy rzeczami, tak jak i ideami, mogą być wyznaczone z absolutną ścisłością" (Eco 2006: 184). Również w modernistycznym ideale wiedzy zapanował pogląd, że celem nauki winno być dążenie do precyzyjnego odzwierciedlenia podziałów istniejących w naturze oraz odkrycia praw nią rządzących. Szczególnie w wiekach XVII i XVIII oświeceniowi uczeni zajmujący się historią naturalną, podejmowali z pasją zagadnienie klasyfikowania na nowo świata przyrody. Kategoryzowanie to - wich mniemaniu - miało przede wszystkim sens empiryczny, a więc odnoszący się faktycznie do rzeczywistości. Zasady Arystotelesowskiej kategoryzacji - w postaci systematyzacji (taksonomii) - odgrywały szczególnie ważną rolę w takich naukach, jak botanika czy zoologia. Milcząco przyjmowano wówczas zasadę autonomii poznawczej podmiotu oraz klasyczną (też wywodzącą się od Arystotelesa) koncepcję prawdy, z którą związana jest ontologia i epistemologia realizmu (tzw. mit obiektywizmu), a u podstaw której leży intuicja odwzorowania obrazującego (Chwedeńczuk 1984: 34, 42). Coraz dokładniejsza obserwacja oraz szczegółowe opisywanie, mierzenie, liczenie, ważenie itp. tego wszystkiego w przyrodzie, co dawało się ująć w sposób ilościowy, stało się głównym celem naukowego poznania. W sukurs naturalistom szło powstawanie wciąż doskonalonych narzędzi badawczych. Konstruowanie bardziej precyzyjnych przyrządów pomiarowych sprzyjało z kolei wyodrębnianiu się nauk szczegółowych. W drugiej połowie XVIII wieku zrodziła się zmatematyzowana geografia fizyczna, mająca ambicję formułowania uniwersalnych praw, których „wszystkie f e n o m e n a przyrodzone są koniecznym wypadkiem" (Śniadecki 1804: III). Wtedy także nastąpił wyraźny rozwój kartografii, czego wyrazem było m.in. wykonywanie map topograficznych¹. Dzięki wynalezieniu niemal wszystkich ważniejszych narzędzi mierniczych i zastosowaniu ściślejszych metod pomiarów, doszło w pierwszej połowie XIX wieku m.in. do powstania nowoczesnej geografii. „Nowa fizyczna i porównawcza geografia traktuje przedmiot w oderwaniu pojęć natury od historycznych i etnograficznych stosunków i od politycznych granic"

1 Np. z rozkazu cesarzowej Marii Teresy austriacki sztab generalny kwatermistrza przystąpił w 1763 r. do realizacji wielkiego przedsięwzięcia kartograficznego, obejmującego kraje wchodzące wówczas w skład monarchii Habsburgów. W ramach tzw. zdjęcia józefińskiego powstała w latach 1779-1783 m.in. rękopiśmienna mapa topograficzna Galicji, potocznie zwana u nas mapą Miega. Ze względu na swoje znaczenie militarne była ona przez dłuższy czas utajniona. W latach 1806-1862 prowadzono II. tzw. franciszkowskie, zdjęcie wojskowe krajów monarchii, a w 1869 r. przystąpiono do wykonywania III zdjęcia (franciszko-józefińskiego). 
(Pol 1878: 5). Za twórców jej podstaw uważani są niemieccy badacze Alexander von Humboldt i Karl Ritter.

Śladami Humboldta i Rittera podążał u nas Wincenty Pol, który wcześniej dał się poznać jako patriotycznie zorientowany, kochający ojczystą przyrodę i lud, poeta romantyczny. Nie tylko na miano jednego z ojców polskiej geografii nowożytnej, lecz także etnografii polskiej zasłużył on sobie w szczególności dzięki badaniom prowadzonym w Karpatach, którym przypisywał wyjątkowe znaczenie zarówno dla geografii, jak i etnografii. Pol postanowił naszkicować obraz etnograficznego zróżnicowania górali zamieszkujących północne stoki Karpat, tylko pod względem ich geograficznego rozgraniczenia. Za autorem tzw. Latopisu Nestora przyjął nazwę „rodów” na oznaczenie "małych plemiennych grup”. „Rozrodzona rodzina jest rodem. Na stanowisku tedy rodu staje człowiek pośrodku roślinnych i zwierzęcych grup, i wyżej jak do rodu, nie posuwa natura stowarzyszeń ludzkich” (Pol 1850: 19). Innymi słowy, „Człowiek na stanowisku rodu stojący należy do natury" (Pol 1851: 111). Według Pola skupienie czy ześrodkowanie jest „wszelkim warunkiem twórczości i życia w naturze” (Pol 1850: 16) Przyroda koncentruje się więc w swojej twórczości, chcąc wydać zjawiska odrębne, dlatego stwarza tylko niewielkie grupy stowarzyszeń. „Natura tworzy szczegóły, indywidualizuje i zawiązuje małe kółka rodowe" (Pol 1847: 437). W górach przyroda szczególnie „działa w skupieniu”, dlatego też i rodowość jest tam najbardziej wyrazista, a więzi rodowe są wyjątkowo mocne (Pol 1851: 112; 1869: 179). Na ograniczonym naturalnymi granicami obszarze tworzą się więzi rodowe „i to co jest krwią, narzeczem, obyczajem, sposobem życia i zarobkowania miejscowo z sobą powiązane, co się ma za coś odrębnego, i od innych za to jest miane, nazywamy r o d e m" (Pol 1851: 111). Każdy ród ma widoczny już na pierwszy rzut oka swój odrębny wyraz, stanowiąc jakby organiczną całość (Pol 1850: 19).

Etnograficzny opis rodów góralskich na północnych stokach Karpat przedstawił Pol w ujęciu synchronicznym, „a więc cały ród, jak dziś żyje i siedzi, bez względu nawet na historyą jego osiedlenia" (Pol 1851: 112). Zrobił to w trzech aspektach:

- po pierwsze, pokazując jak natura wpływa na odgraniczenie rodów, jak się odpowiednio do rzeźby gór zawiązują węzły rodowe (Pol 1851: 112). Chociaż bowiem o rozprzestrzenianiu się i rozszerzaniu geograficznym danego rodu decyduje głównie ,jego siła wewnętrzna, plemienności siła rozrodzenia się", to „odgraniczenia się jego od sąsiednich rodów, stanowi jednak zawsze miejscowe położenie ziemi" (Pol 1966: 190). Terytorium odgrywa pod względem tego rodzaju rozgraniczeń największą rolę i obok siły plemiennej pewnego rodu, decyduje "głównie i o liczbie, w której się rozrodził i o kierunku, w którym się rozkrzewia, lub dalej już rozradzać nie może" (Pol 1851: 113). Za Ritterem przyjął Pol też dwa pewniki. Pierwszy z nich głosił, że wody rzek sprzyjają zawiązywaniu i umacnianiu się społecznych więzi, „bo ród każdy bierze zawsze wagę tylko za wodą" (Pol 1851: 115; Pol 1878: 13). Natomiast 
za czynnik o najważniejszym znaczeniu dla terytorialnego rozgraniczenia rodów uznawał wododzielne pasma górskie. „Wielkie góry stanowią znowu granicę pomiędzy klimatycznymi i etnograficznymi stosunkami” (Pol 1878: 14);

- po drugie, określając jak się każdy ród sam nazywa, lub przez innych jest zwany, jaki obszar zajmuje na mapie i gdzie go szukać należy (Pol 1851: 112);

- po trzecie, obejmując zakresem swoich etnograficznych zainteresowań całą Góralszczyznę ${ }^{2}$,na północnych stokach Karpat od źródeł odrzańskiej Ostrawicy, aż do źródeł Suczawy" (Pol 1851: 112).

Podziału ludności góralskiej dokonał Pol na trzy „grupy etnograficzne” - Góralszczyzny zachodniej, środkowej i wschodniej części Karpat - analogicznie do tego, jak się sam łuk tych granicznych gór rozpada na trzy główne części, ściślej z sobą połączone (Pol 1851: 113).

W niniejszym artykule zajmiemy się bliżej tylko Góralszczyzną polską, obejmującą polskich Górali zamieszkujących niemal całą zachodnią część Karpat. Według współczesnej nomenklatury geograficznej jest to fragment Karpat Polskich, obejmujący znaczną większość północnego obszaru Karpat Zachodnich, czyli Zewnętrzne i Centralne Karpaty Zachodnie (Warszyńska 1995: 9-10). Pol pisał, że „Górale nazywają sam grzbiet graniczny, od źródełWisły do źródeł Świecy dniestrowej - Beskidem" (Pol 1869: 172). Natomiast Ludwik Zejszner twierdził, że lud "nie zna tej nazwy, tylko pojedyncze góry Bieskidem mianuje" (Zejszner 1848: 99). Beskid na zachodzie rozpoczyna się od gór Jabłonek (Przełęcz Jabłonkowska), skąd ciągnie się kilkoma podłużnymi pasmami. „Kierunek główny tych działów jest od zachodu na wschód, aż po wyłom Dunajca, który grzbiet ich przerwał na przestrzeni od Sącza do Wojnicza w poprzek" (Pol 1869: 172). Tę część Beskidów nazwał Pol Beskidem Zachodnim i podzielił go na Beskid Śląski, Beskid Węgierski (Orawski) i Beskid Polski (Pol 1878: 30).

\section{W poszukiwaniu zewnętrznych granic Góralszczyzny}

Wincenty Pol interesujący się również historią poznania Karpat stwierdził, że były one znacznie wcześniej „w całym naukowym świecie znane niż u nas” (Pol 1869: 52). Istotnie, europejscy, a głównie niemieckojęzyczni badacze, już w XVII i XVIII wieku opisywali przede wszystkim przyrodę Tatr (Szaflarski 1972; Węglarz 2010). Za tło prowadzonych badań przyrodniczych służyła od 1790 roku mapa geograficzna Galicji, tzw. mapa Liesganika. „Ta karta wzbogaciła wiedzę geografii powszechnej (...). Słusznie tedy potrzeba ją policzyć w literaturze za wielkie zasadnicze dzieło, które wyświeciło umiejętnie po raz pierwszy ogólny i prawdziwy obraz tego kraju" (Pol 1847: 448). Pisząc oficjalnie, że „pod względem wiedzy geograficznej pozostaje wartość tego dzieła

2 Określenie „Góralszczyzna”, notowane w słownikach poprawnej polszczyzny, nie cieszy się jednak powszechnym uznaniem wśród polskich etnografów. Niemniej jednak od XIX w. było i jest obecnie używane w znaczeniu obszaru zamieszkanego przez Górali, lub samych Górali, albo też - wtedy pisane przez małe "g" - całości góralskiej kultury (Paryscy 1995: 357). 


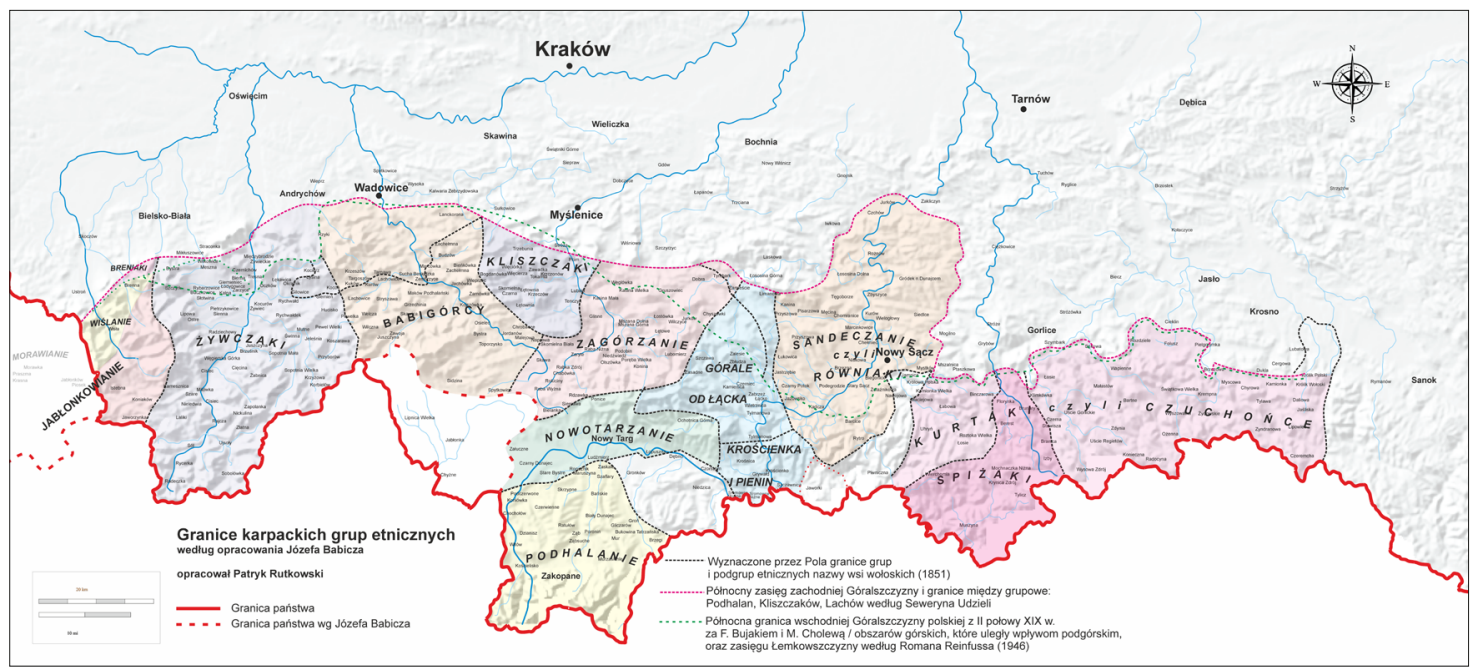

II. 1.

Granice karpackich grup etnicznych wg opracowania Józefa Babicza

niewzruszoną” (Pol 1847: 447), wykazał się Pol swoistą „dyplomacją”. W jednym z listów do żony, pisanych w trakcie podróży odbywanej z Janem Kantym Łobarzewskim latem 1840 roku po Karpatach Wschodnich, informował, że wspólnie opracowują nową mapę gór. Uznawana bowiem dotąd za najlepszą tzw. karta Liesganika, jest bardzo niedokładna, a nawet błędna. „Tylko kontur rzek główniejszych jest dobrze podany, lecz kierunek gór i ich kształt jest bardzo fałszywie oznaczony" (Pol 1878: 161) Także w zakończeniu Rzutu oka na północne stoki Karpat... twierdził, że nie zamieścił tam mapy przede wszystkim z tego powodu, iż najlepsza z dostępnych dotąd kart, nie dałaby wystarczającego obrazu szczegółów opisem tym objętych (Pol 1851: 132).

Również nie umieszczając na mapach, ale jednak dostrzegając cechy charakterystyczne Górali i Góralszczyzny, jako jedni z pierwszych na marginesie badań przyrodniczych i w relacjach z podróży po Karpatach, uwzględniali je w opisach m.in.: Baltazar Hacquet (1790-1796), Józef Rohrer (1804), Samuel Bredetzky (1810), Emanuel Kratochwil de Kronbach (1820), Teodor Mundt (1840) i in. Spośród polskich uczonych „odkrył” na przełomie XVIII i XIX wieku Karpaty, a przede wszystkim Tatry i Górali tatrzańskich, Stanisław Staszic (1815). Około połowy XIX wieku polska Góralszczyzna stawała się u nas coraz bardziej znana nie tylko dzięki Polowi, lecz także Ludwikowi Zejsznerowi (1844; 1845; 1848; 1849; 1850; 1851; 1852; 1853), Sewerynowi Goszczyńskiemu (1853), Ludwikowi Delaveaux (1851) i innym jej badaczom (Węglarz 1997).

Określenie etnograficznych granic polskiej Góralszczyzny okazało się niełatwe. Zasadniczo uważano, że będzie można je wyznaczyć odwołując się głównie do zasady naturalizmu przedmiotowego, zakładającego „ścisły związek człowieka z naturą, który w coraz innej okolicy typowej, coraz się inaczej wyraża” (Pol 1869: 4). Stosunkowo 
najłatwiej można taką granicę wskazać na południu, gdzie pod względem geograficznym za decydującą uważano „wododzielność”. Biegi rzek na interesującym nas tutaj obszarze Karpat są na ogół konsekwentne, czyli zgodne z nachyleniem pierwotnej powierzchni z południa na północ (z wyjątkiem Olzy, Czarnej Orawy i Strwiąża). „W Karpatach, wzdłuż długiego odcinka granicy państwowej przebiega europejski dział wodny oddzielający dwa zlewiska: Morza Bałtyckiego i Morza Czarnego" (Dynowska 1995: 49-50). Taką też granicę przyjął Pol uważając, że w opisach najlepiej trzymać się granic, które wskazała sama natura. „Tam, gdzie im natura kres położyć chciała, ma się kończyć opis" (Pol 1878: 22). Wiadomo jednak, że również poza tak wyznaczoną granicą były wioski polskie (Zejszner 1853; Zawiliński 1893; 1896).

Granica zachodnia była określona zarówno przez geografię (Przełęcz Jabłonkowska), jak i sytuację polityczną. Nieco większy problem stanowiło określenie etnograficznej granicy wschodniej polskiej Góralszczyzny. Do końca II wojny światowej i akcji „Wisła”, granicę tę stanowiła Łemkowszczyzna (terytorium Łemków, Górali ruskich, Rusnaków, Rusinów). Jednakże zdaniem Pola to grybowski dział zamyka obszar Góralszczyzny polskiej (Pol 1869: 214-215). Z kolei Zejszner przesunął tę granicę dalej w kierunku wschodnim. „Linia z północy na południe poprowadzona do Rymanowa jest granicą wschodnią - odtąd poczynają się Górale-Rusini (...)" (Zejszner 1848: 528). Dodał on poza tym, że pod względem etnograficznym bardzo ważna jest sąsiadująca ze Szczawnicą Szlachtowa. „Wioskę tę zamieszkują Rusini greckokatolickiego wyznania. Jest to koniec zachodni tego plemienia, wylatujący dotąd na zachód prawie klinem, coraz dalej na wschód znacznie rozszerza się ten lud i zajmuje całe Karpaty i z nimi stykające się równiny" (Zejszner 1848: 507). Seweryn Udziela potwierdzał, że już pod Szczawnicą stykają się Górale polscy z Góralami ruskimi, tak zwanymi Łemkami. „W powiecie nowosądeckim, idąc granicą północną, znajdujemy wsi Rusnaków: Wierchomla, Złotne, Barnowiec, Łabowa; w powiecie grybowskim: Binczarowa, Florynka, Wawrka" (Udziela 1918: 87).

Największy jednak problem był ze wskazaniem granicy północnej, albowiem tak ze względów fizjograficznych, jak i społecznych oraz kulturowych, sprawa była tu dosyć skomplikowana. W publikowanych opisach Góralszczyzny jej mieszkańcy występowali zasadniczo w opozycji do „ludu równin”, „Równiaków”, „Dolaków” czy też „Podolaków”. Wyłaniał się w związku z tym problem ustalenia granicy między Góralami i ludem zamieszkałym na równinach, a tym samym wyznaczenia północnego zasięgu Góralszczyzny. Austriacki urzędnik Józef Mehoffer, jako jeden z pierwszych wskazał na tzw. gościniec wiedeński jako północną granicę Góralszczyzny, w opisanym przez siebie cyrkule wadowickim (Mehoffer 1843). Przede wszystkim jednak i tutaj odwoływano się do warunków fizjograficznych. Zejszner pisał, że warunki geograficzne wywierają największy wpływ na jego mieszkańców. „Ważność tej prawdy przedstawiają najjawniej kraje górzyste, wysokie, głębokimi dolinami porozdzierane, w których spodku bystre strumienie płyną; ostry klimat, rośliny i zwierzęta nadają krajom 
właściwą fizjonomię a człowiekowi zupełnie odrębny charakter" (Zejszner 1844: 113). W górach zmienia się od razu charakter kraju. „Postać jego zewnętrzna, roślinność i ludzie, są tu zupełnie odmienne" (Zejszner 1848: 382).

Dodatkowo tę odmienność potęgowało odgraniczenie przez naturalne bariery geograficzne, jakimi są góry (Zejszner 1844: 149). Zdaniem Seweryna Goszczyńskiego lud góralski „z natury swojego położenia, nie łatwo przyjmuje obce, jeszcze trudniej puszcza swoje” (Goszczyński 1853: 129). Na równinach znacznie bardziej „wpływały na stosunki i charakter ludności wypadki dziejowe niż w niedostępnych górach, których mieszkańcy rozwijali się dlatego prawie wyłącznie pod przeważnym działaniem potęg natury" (Tatomir 1874: 82-88). Izydor Kopernicki twierdził, że przez to odizolowanie wśród Górali „trwalej niż u innych mieszkańców przechowują się pewne właściwości rodowe (...)” (Kopernicki 1877: 109). Innymi słowy, góry i Góralszczyzna to po prostu „inny świat”: „Dziwny ten świat górski! Niewielka przestrzeń oddziela go od nadwiślańskich równin, nierównie mniejsza od karpackiego podgórza - a przecież wszystko tu inne (...)" (Anczyc 1874: 341)

Zwolennicy naturalizmu przedmiotowego byli przekonani o istnieniu bezpośredniej zależności i determinującego wpływu ram przyrodniczych na człowieka, życie społeczne i kulturę (Węglarz 2017: 70-71). Franciszek Siarczyński pisał, że górale należą do ludów w Galicji, „które położeniem kraju i siedzib swoich oddzielone od innych, jak miejscem, tak postawą, obyczajami i ubiorem są od nich dalekie (...)" (Siarczyński 1827 196). Pół wieku później Łucjan Tatomir twierdził, że głównie ze względu na odmienne warunki przyrodnicze, wśród mieszkańców Galicji wyróżniają się przede wszystkim dwie grupy: mieszkańcy gór, czyli Górale, oraz mieszkańcy równin, czyli Równiacy (Tatomir 1874: 64-65). Jeszcze na początku XX wieku utrzymywano: „Góralszczyzna stanowi jakby odrębny świat w stosunku do równin. I nic dziwnego. Natura stworzyła inne warunki bytu dla Górali, inne dla Równiaków (...)" (Bogatyński 1912: 66). Dlatego też „Górale wydawali się mieszkańcom dolin jakąś grupą dość obcą; odmienne warunki kształtowały ich życie, inne też oddziaływały tu wpływy kulturalne" (Bystroń 1976: 14)

W szczególności te dwie grupy ludności wyraźnie odróżniały się od siebie strojem: „Górale, a z niemi Podhalanie różnią się ubiorem od mieszkańców równin; zastosowali go całkiem do właściwości swojego kraju” (Zejszner 1851: 538-539). „Strój całej Góralszczyzny jest w ogóle krótki i obcisły, a ciepły i lekki, zastosowany do ostrego klimatu i uciążliwego wspinania się po górach" (Tatomir 1874: 68). Charakteryzując ogólnie góralszczyznę, opisywano również specyficzny rodzaj i kształt tamtejszych osad, budownictwo, wygląd fizyczny i cechy charakteru, pożywienie, zajęcia, niekiedy też gwarę, wierzenia i inne elementy kultury (Tatomir 1874: 68-82; Gustawicz 1881: 458). Roman Reinfuss, podsumowując prowadzone tuż po II wojnie światowej badania nad ustaleniem granicy pomiędzy Góralami i Krakowiakami, pisał: „Na pograniczu krakowsko-góralskim różnice, zachodzące w tradycyjnym stroju ludowym, również urastały, obok różnic gwarowych, do roli głównych kryteriów, według których Górale i Lachy rozpoznawali swoich od obcych" (Reinfuss 1946: 230). 
Wykorzystywano też, w charakterze kryterium odróżniającego mieszkańców gór od mieszkańców równin, poczucie odrębności w świadomości grupowej (kryterium etnosocjologiczne), lecz w uproszczonej postaci funkcjonujących etnonimów. Przy tym przeważnie nie uwzględniano ich zróżnicowania na nazwy własne (endoetnonimy) i określenia nadawane przez innych (egzoetnonimy). Różnica ta jest bardzo istotna, bowiem pojęcie danej społeczności powinno wyrażać się w nazwie, ,jaką społeczeństwo sobie daje (a nie w - przeważnie niedokładnej - nazwie, jaką jemu się daje) oraz w bardzo mocnym poczuciu wspólnoty, którą tworzy" (Mauss 1973: 818). Przykładowo: lud w równinach osiadły, nazywa wszystkich mieszkańców gór Góralami (Pol 1869: 172). W kierunku zachodnim od Wadowic góry zamieszkują Górale, a kraj pagórkowaty Polacy i dwa te szczepy polskie nienawidzą się nawzajem od niepamiętnych czasów (Zejszner 1850: 429). Jeszcze częstszym egzoetnonimem, używanym przez Górali na określenie sąsiadów z północy, był „Lach”. „Z mieszkańcami równin, z Lachami, górale nie mają fizycznie prawie nic wspólnego; zdaje się, że to są zupełnie inne plemiona, mówiące tylko jednym językiem" (Zejszner 1851: 535). Według Waleriana Serwatowskiego Górale polscy, zamieszkujący góry ówczesnych cyrkułów wadowickiego i zachodnią część sądeckiego, odróżniają się „jako osobny szczep od Lachów, czyli mieszkańców równin" (X.S. 1851: 36). Górale zarówno mieszkańców równin, jak i Podgórzan nazywają Lachami, a czasami Krakowiakami (Pol 1869: 191). Zdaniem Antoniego Schneidera, „Lachami nazywają Górale zwykle mieszkańców miast i z nizin w kraju" (Schneider 1871: 104). Walery Eljasz twierdził, że „Górale nasi inaczej nie zowią mieszkańców z równin jak lachami” (Eljasz 1874: 249). Ambroży Grabowski pisał, że "Górale nazywają Lachami lud wiejski z równin pod górami, różniący się ubiorem od mieszkańców gór, a tym jest kitla albo suknia zwierzchnia z Inianego płótna (płóciennica)" (Grabowski 1909: 360). Stanisław Eljasz-Radzikowski podkreślał, że Lachy to nie nazwa własna, lecz przezwisko nadawane przez sąsiadów (Eljasz-Radzikowski 1900: 303).

Jak zatem przebiegała granica między Góralami i ich sąsiadami z północy? W dokonanym przez siebie podziale Góralszczyzny, Pol wskazywał na miejscowości graniczne. Natomiast jako pierwszy po Polu spróbował granicę tę na całej długości określić dopiero Seweryn Udziela, który korzystał z ustaleń Pola, badań własnych oraz przeprowadzonych przez Władysława Kosińskiego (Udziela 1918: 86-87). Inni badacze, przede wszystkim wykorzystując do tego celu opozycję Górale - Lachy, różnie oznaczali tę granicę (Jakóbiec 1901; Bujak 1902; Młynek 1903; Cholewa 1946). Na zamieszczonej przez Reinfussa mapce przedstawiającej północne granice polskiej Góralszczyzny - według W. Pola, S. Udzieli, F. Bujaka i innych badaczy - tylko na krótkich odcinkach poszczególne linie pokrywają się ze sobą, wykazując poza tym dosyć znaczne rozbieżności (Reinfuss 1946: 229). Reinfuss podkreślał historyczną zmienność granic Góralszczyzny - jej cofanie się w kierunku południowym - jak również sam przesunął tę granicę, wyłączając z jej obszaru grupę tzw. Lachów sądeckich (Reinfuss 1946: 224). 


\section{Wewnętrzne podziały Góralszczyzny}

Ustalając linię demarkacyjną pomiędzy Góralami i Lachami (Równiakami itp.) początkowo milcząco zdawano się przyjmować założenie, że mieszkańcy gór - podobnie jak podgórza oraz równin - byli przynajmniej względnie jednolici. Miało to być konsekwencją podobieństwa warunków geograficzno-przyrodniczych, w których żyli. Przy bliższym oglądzie okazało się jednak, że tak wcale nie jest. Zarówno elementami tzw. charakteru wewnętrznego, jaki charakteru zewnętrznego - tj. cechami psychicznymi, gwarą, wyglądem fizycznym, strojami, budownictwem itd. - różnili się między sobą zarówno Górale, jak i pozostałe grupy nie-góralskie. Walerian Serwatowski pisał, że „W górach różnice plemion i pokoleń wydatniejsze są jak na równinach” (X.S. 1851: 36) Zdaniem Łucjana Tatomira „Przyroda, rozgraniczając w górach ściśle doliny walne i okolice międzygórskie mniej lub więcej dostępnymi działami, nie łączy, lecz raczej dzieli ludzi. Stąd w Góralszczyźnie największa panuje rozmaitość rodów i najmniej one tam ze sobą są zmieszane" (Tatomir 1874: 65). Według Erazma Czechowicza, "Szczepy górali tak polskich jak ruskich rodowymi znamiony więcej od siebie się różnią, aniżeli mieszkańcy kraju otwartego" (Czechowicz 1884: 31). Ta wielość grup (rodów) góralskich dawała badaczom do myślenia. O ile zrozumiałe bowiem wydawały się różnice pomiędzy Góralami z jednej, a Podgórzanami (Równiakami) z drugiej strony,

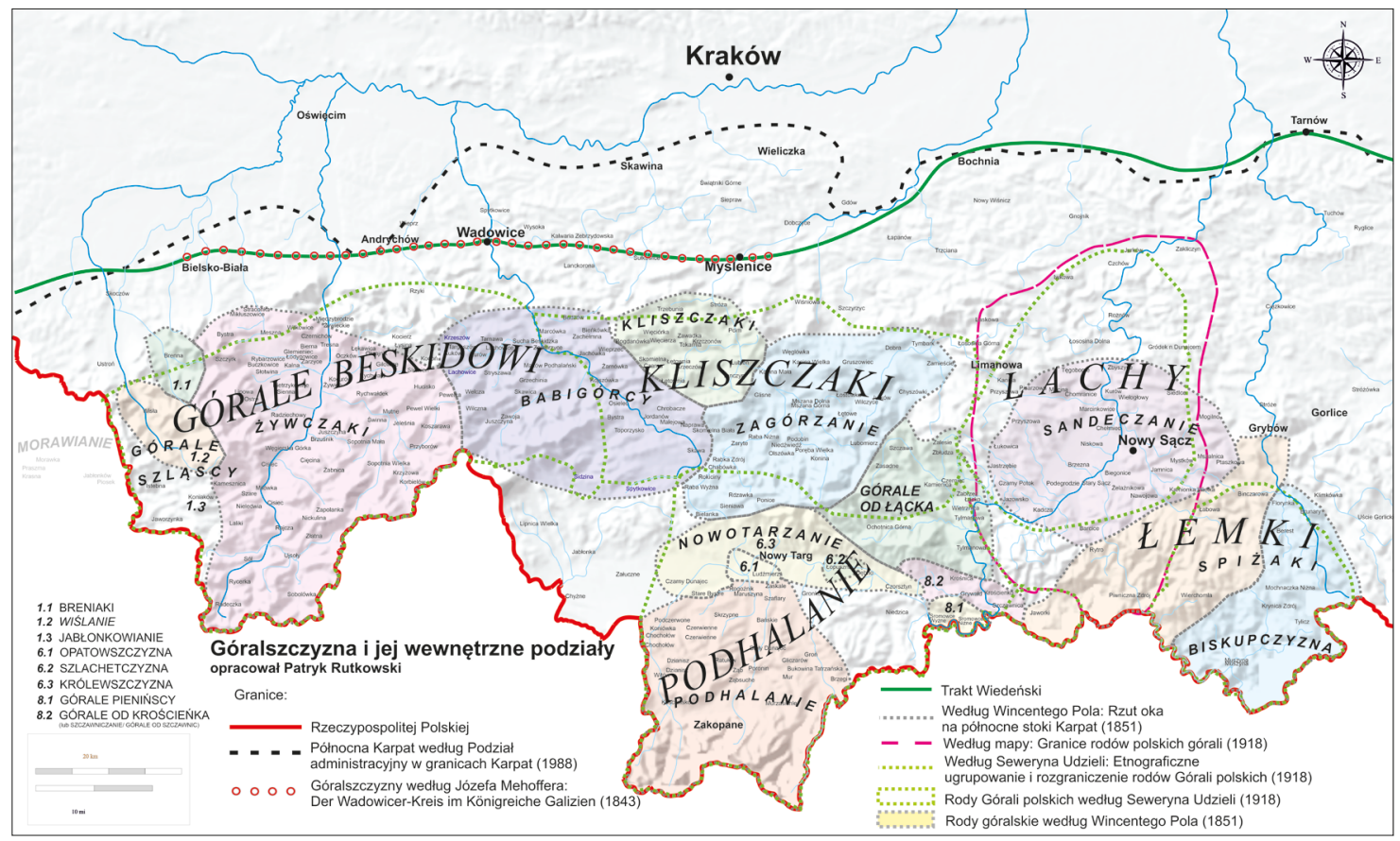

II. 2.

Góralszczyzna i jej wewnętrzne podziały 
to różnice wewnątrz tych grup były z punktu widzenia naturalizmu przedmiotowego czymś zagadkowym: „Mniej zrozumiałe są różnice i właściwości odrębne w łonie samej góralszczyzny karpackiej. Lecz i tutaj zapewne nic innego, jak warunki fizyczne, taką odznaczające się w górskich okolicach rozmaitością, musiały na to wpłynąć" (Bogatyński 1912: 66). Ponownie zatem odmienności geograficzno-fizjograficzne w obrębie gór powodować miały zróżnicowanie etnograficzne w obrębie Góralszczyzny.

Pol przedstawił następujący podział Górali polskich na rody i ich „pomniejsze odcienia”, które są „tylko miejscowo znane”. Poczynając od zachodu, byli to:

1. Górale śląscy, czyli Jabłonkowianie;

1.1. Jabłonkowianie (właściwi);

1.2. Wiślanie (zamieszkujący miejscowość Wisłę);

1.3. Breniaki (zamieszkujący miejscowość Brenną);

2. Żywczaki, czyli Górale od Żywca i Ujsoł;

3. Babigórcy, czyli Górale od Babiej Góry, Jordanowa i Suchej;

4. Zagórzanie, zwani też Rabczanami lub Góralami od Rabki;

5. Kliszczaki, czyli Górale od Łętowni;

6. Nowotarzanie, nazywani także Góralami od Nowego Targu lub z Nowotarskiej Kotliny;

6.1. Opatowszczyzna;

6.2. Szlachetczyzna („szlacheczyzna”);

6.3. Królewszczyzna;

7. Podhalanie, czyli Górale od Tatr lub Górale tatrzańscy;

8. Górale od Pienin, Krościenka i Łącka;

8.1. Górale Pienińscy;

8.2. Górale Krościeńscy;

8.3. Górale od Łącka;

9. Sandeczanie, czyli Górale od Sącza, zwani też Góralami Sandeckimi lub Równiakami. Wymienił on też szczegółowo miejscowości zamieszkiwane przez poszczególne rody (Pol 1851: 113-123).

Taką klasyfikację rodów Górali polskich sporządził Pol na podstawie własnych obserwacji poczynionych w trakcie podróży po Karpatach, jak również dzięki informacjom uzyskanym głównie od Andrzeja Cinciały z Cieszyna i Ludwika Kamińskiego z Nowego Targu (Pol 1851: 132). Do podziału przedstawionego przez Pola ugrupowania rodów Górali polskich nawiązywali niemal wszyscy późniejsi etnografowie zajmujący się Góralszczyzną. Niektórzy dokładnie go cytowali (Konopka 1874; Lutostański 1874; Tatomir 1874; Gustawicz 1881; Zakrzewski 1888), inni wprowadzali pewne zmiany w szczegółach (Wrześniowski 1882), jeszcze inni modyfikowali przebiegi granic na niektórych odcinkach (Jakóbiec 1901; Bujak 1902; Młynek 1903; Cholewa 1946; Reinfuss 1946).

Niemal rewolucyjnej zmiany dokonał Udziela utrzymując, że Pola „podział opierał się tylko na samych nazwach, bądź to nadawanych mieszkańcom jednej wsi przez sąsiadów, bądź też określających miejsce, z którego pochodzą" (Udziela 1918: 83). 
Jednakże, pomimo takiego zróżnicowania rodów góralskich w nazwach, na przykład Górale śląscy niczym się nie różnią od innych Górali beskidzkich. Dlatego Udziela zredukował liczbę rodów Górali polskich, zamieszkujących północne stoki Karpat do czterech, zamiast dziewięciu wyróżnionych przez Pola. Za główne kryterium podziału, posłużyły mu różnice w stroju męskim i sposobie budowy chałup. Wymienił on następujące rody: Górali beskidowych, Podhalan, Kliszczaków i Lachów (Udziela 1918: 88-90). Podział ten przejął - z drobnymi modyfikacjami - Jan S. Bystroń (Bystroń 1925), a później inni etnografowie (Fischer 1934). W okresie międzywojennym zaprzestano używać nazwy „rody”, a mówiono o "grupach” z różnymi przymiotnikami: etnicznych, etnograficznych, górskich itp.

Nie tylko jednak warunki naturalne, lecz także wynikające z nich warunki życia, sposoby zarobkowania, jak również oddziaływanie sąsiednich społeczności i związane z tym tzw. obce wpływy, spowodowały podział Góralszczyzny na wiele rodów. Odróżniają się one bowiem pomiędzy sobą nie tylko samym miejscem zamieszkania i nazwami, lecz także strojem, gwarą, zwyczajami itd. Około połowy XIX wieku wprowadzono na przykład podział polskich Górali na „białych” i „czarnych”. Według Zejsznera wieś Stróża „stoi na granicy góralszczyzny”; odtąd na południe „zamieszkują górale w brunatnej guni; chłopa bowiem w białej sukmanie nie masz nigdzie pomiędzy górami" (Zejszner 1848: 477). Zdaniem Serwatowskiego Górale czarni „głębsze zamieszkują góry, czarne pospolicie noszą na sobie z grubej wełny górnice, i mniej są zmieszani z Lachami. Biali więcej zbliżeni do Lachów, (...) białe pospolicie z grubej wełny noszą górnice, i niejako pośredniczą między Lachami a czarnymi góralami” (X.S. 1851: 36). Natomiast Goszczyński twierdził: „W takiej okolicy leżą Kamienica, Ochotnica i Tylmanowa, zamieszkane przez górali zwących się białymi, dla różnicy od górali czarnych, którzy się gnieżdżą w głębszych już górach" (Goszczyński 1853: 43). 0 tym podziale dowiedział się on podczas pobytu w Mikołajowicach pod Tarnowem, gdzie Górali rozróżniano kierując się kolorem noszonej przez nich guni - „mieszkają więc górale c i s c i (czyści) w Tatrach, c z a r n i , czyli główni, na górach, b i a l i bliżej ku Lachom" (Bystroń 1927: 114). Późniejsi podróżnicy różnie lokalizowali Górali białych i czarnych. Na przykład Oskar Flatt pisał, że „Krościenko jest stolicą Białych Górali, tzw. od białych opończy” (Flatt 1859: 109). Inny podróżnik utrzymywał, że „Krościenko zaludnione przez Górali białymi zwanych, dlatego że całe ubranie i płaszczyki noszą białe, kiedy inni, np. nowotarscy, maniowscy, noszą płaszcze ciemne" (Nowakowski 1858: 147).

Reasumując: zarówno przy wykorzystaniu zasady naturalizmu przedmiotowego, jak i biorąc pod uwagę wyróżniki kulturowe, nie udało się etnografom dokonać precyzyjnej delimitacji rodów czy grup etnograficznych również w obrębie samej Góralszczyzny. Mapkę prezentującą kontury rozmieszczenia rodów góralskich według Pola i Udzieli opracowała tuż przed II wojną światową Maria Bytnarówna, wedle wskazówek Jana S. Bystronia (Bystroń 1939: 120-121). Natomiast szczegółową mapę podziatów oraz zasięgi polskiej Góralszczyzny i wchodzących w jej skład grup etnograficznych, 
według Pola, Udzieli i innych badaczy opracował dopiero Józef Babicz (Babicz 1966). Dodajmy, że po II wojnie światowej - w zmienionych w jej wyniku oraz akcji „Wisła" warunkach - nadal starano się dokonywać etnograficznych regionalizacji Polski, w tym także Góralszczyzny, próbując w niektórych przypadkach prezentować je na mapkach (Kamocki 1965; Kutrzeba-Pojnarowa 1967; Kopczyńska-Jaworska 1969; Kłodnicki 1995). Krytyczną analizę prób etnograficznych regionalizacji - w tym kultury karpackiej - w polskiej myśli etnologicznej, przeprowadziła Anna Kutrzeba-Pojnarowa (Kutrzeba-Pojnarowa 1977).

\section{Od substancjalnej do prototypowej koncepcji zróżnicowania etnograficznego}

W tradycji kultury europejskiej można wyróżnić dwa modelowe rozumienia „granicy”. Pierwsze, nazwane substancjalizmem (esencjalizmem) i związane z Arystotelesowską teorią kategoryzacji, scharakteryzowaliśmy ogólnie na wstępie tego artykułu. Jego zasady były i wciąż są obowiązujące w modernistycznym (oświeceniowo-pozytywistycznym) paradygmacie naukowego poznania nie tylko w przyrodoznawstwie, ale też - zgodnie z wyznawaną tezą naturalizmu metodologicznego - w dyscyplinach zwanych niegdyś naukami o duchu lub/i historycznymi, a dzisiaj humanistycznymi i społecznymi. Drugie stanowisko, które w przeciwieństwie do Arystotelesowskiego umownie można określić „pitagorejsko-platońskim”, traktuje granice jako coś względnego. W tym rozumieniu wszelkie granice są raczej konwencjonalne i „przenikalne”, a poszczególne byty mogą wręcz przekształcać się w inne byty. Pogląd taki prowadził m.in. do stanowiska zwanego „metamorfizmem” lub „transformacjonizmem”, które dominowało w premodernistycznym ideale wiedzy, a od czasów oświecenia stopniowo zostało uznane za nienaukowe oraz domenę religii, magii oraz folkloru (Durkheim, Mauss 1973: 709).

Rozterkę, jaką mogli mieć niektórzy uczeni w opowiedzeniu się po stronie któregoś z powyższych stanowisk jeszcze w połowie XIX wieku, dobrze przedstawił Pol. Twierdził on, że z jednej strony ludzki umysł „tęskni wiecznie za tak określoną całością, która sama w sobie zamknięta, wystarcza sobie i czysto ludzkim stosunkom człowieka" (Pol 1869: 114). Z drugiej strony, na stałym lądzie nie ma jednak ścisłych konturów i takiej „zaokrąglonej całości”, jaką przykładowo jest wyspa. „Góry spływają tu w doliny, doliny mają swoją wierzchowinę i swoje porzecza, rzeki mają krainę źródłowisk i ujścia. Działy roztaczające wody ku osobnym obszarom wodnym nie są ściśle odznaczone, słowem obszar stałego lądu płynie (...)" (Pol 1869: 114). Strefy czy dziedziny roślinności także nie są odcięte od siebie ostrymi granicami, lecz przechodzą jedna w drugą nieznacznie przez pogranicza lub łączą się jedna z drugą, za pośrednictwem bliskich lub pokrewnych typów. „Stąd powstają w Europie pomniejsze stowarzyszenia roślin, dzielnice odrębnej roślinności i ogniwa przechodnie (...)" (Pol 1870: 327). Na przykład lasy tworzą taką „całą dzielnicę roślinności, mającą swe 
odrębne życie połączone tą tajemniczą wstęgą, którą się w naturze wiąże każde społeczeństwo" (Pol 1870: 337-338). Lasy, tak jak każda dzielnica roślinności, mają swoje centra, w których rodzaj drzew dominujących w tej dzielnicy, występuje w pełnej sile i w całej okazałości. „Te mateczniki dzielnic roślinnych leżą zwykle pośrodku dzielnicy (...)" (Pol 1870: 348). Księga natury zawiera zatem obrazy „natury miejscowej, wedle odrębnych typów i owego związku, w jakim wszędzie człowiek z naturą stoi i pod jej wpływem zostaje" (Pol 1870: 2).

Wnioski płynące z badań w zakresie geografii roślin, rzucają nowe światło na istotę życia w naturze i mogą być wykorzystane do zjawisk z zakresu wyższych organizmów. „I tak oddzielnym grupom i dzielnicom w roślinności odpowiadają także zawsze pewne i te same stowarzyszenia organizmów zwierzęcych i to w całem stopniowaniu zjawisk, począwszy od drobnych wymoczków, krążących w naczyniach rośliny, a kończąc na człowieku (...)" (Pol 1850: 17). Zdaniem Pola, idea stowarzyszania się istot w naturze jest kluczem do zrozumienia jej tajemnic i powinna być zastosowana również do tych stowarzyszeń, w których człowiek żyje, czyli ludzkich społeczności, tj. rodów i narodów (Pol 1850: 18). Skoro zatem natura - przynajmniej na stałym lądzie - ma właśnie wyżej opisany labilny charakter, to zgodnie z zasadą związku człowieka z ziemią, analogiczny charakter powinna mieć rodowość ludu. Może więc w ugrupowaniu etnograficznym góralskich rodów nie występują ściśle określone linie demarkacyjne pomiędzy nimi? Otóż okazuje się, że poszczególne rody też mają swoje ogniska, gdzie się ich rodowość koncentruje, gdzie ich cechy charakterystyczne są najbardziej wyraziście: "- Targowiska dla spraw światowych. - Miejsca święte odpustami (te zachowują niekiedy znaczenie dla wielu rodów)" (Pol 1966: 188). Są to centra rodowości, w których natura działa w skupieniu, miejsca, „gdzie cechy miejscowe pewnego rodu silnie się wyrażają odrębnością swoją" (Pol 1870: 238).

Ale oprócz tych centrów rodowości, w poszczególnych rodach występują pogranicza kręgów rodowych. Stąd też pomimo znacznej indywidualności rodów, każdy z nich ma ,jednak zawsze zaród w sobie przejścia w ród sąsiedni (...)” (Pol 1966: 188-189). Na przykład, po wymienieniu miejscowości wchodzących w skład królewszczyzny w rodzie Nowotarżan, Pol dodał, że ostatnie pięć wsi jest „ogniwem przechodnim” do Górali pienińskich (Pol 1851: 116). Dalej nad Dunajcem, poniżej Krościenka, można się „najdokładniej przypatrzyć tym drobnym odcieniom rodowości, które się z wolna mienią idąc od wsi do wsi za wodą" (Pol 1851: 117). Różnice zatem występują już pomiędzy pojedynczymi wsiami, należącymi nawet jeszcze do tej samej okolicy, do tego samego rodu (Pol 1966: 188). Cechą „przechodniości” charakteryzują się jednak nie tylko wsie, ale również same rody. Na przykład ród Górali od Łącka stanowi takie pośrednie ogniwo pomiędzy Góralami tatrzańskimi i nowotarskimi a Góralami sądeckimi, ponieważ „siedziby jego ciągną się wąskim pasem ponad wodą na znacznej przestrzeni” (Pol 1851: 117). Ludność zamieszkująca Kotlinę Sądecką i przyległe góry - nazywana przez mieszkańców równin Góralami od Sącza, a przez sąsiadujących z nimi Górali Równiakami - jest też 
grupą pośrednią „z rodów góralskich do podgórskiego ludu, co do sposobu życia, obyczaju i postawy swojej" (Pol 1851: 117). Przejściowość ta wyraża się zarówno od strony zachodniej, gdzie „graniczą” z Góralami łąckimi i nie od razu przejawiają owe cechy wybitne, które ich charakteryzują, jak i od pogranicza południowego, gdzie sąsiadują ze Spiżakami (Pol 1851: 117-118). Zagórzanie z kolei są rodem przechodnim od Górali nowotarskich do Babigórców (Pol 1851: 122). Nawet na rzekomo najwyraźniejszych granicach, pomiędzy trzema głównymi grupami etnograficznymi zamieszkującymi w trzech geograficznych częściach północnych stoków Karpat, istnieją „rody przechodnie" pomiędzy nimi (Pol 1851: 113). Krótko mówiąc, różnice występujące od wsi do wsi, od rodu do rodu sprawiają, „że się wybitne cechy powiatowszczyzny rodowej zacierają zwolna, nieznacznie prawie i w inne przechodzą (...)" (Pol 1966: 189).

Wynika z tego, że klasyczna teoria kategoryzacji mówiąca o wyraźnych granicach, nie uwzględniająca zróżnicowania stopnia przynależności do poszczególnych kategorii itd., nie jest odpowiednia do adekwatnego przedstawienia rzeczywistości społeczno-kulturowej w całym jej zróżnicowaniu. Nie ma tam bowiem ścisłych granic, natomiast istnieją pogranicza (pogranicza bez granic, jak postmodernistyczne kopie bez oryginałów!). Tę - jedną z alternatywnych - koncepcję zróżnicowania etnograficznego można by określić mianem „prototypowej” lub „falowej”. Niestety, na gruncie etnografii Pol jej konsekwentnie nie rozwinął, wniosków nie wyciągnął i w praktyce nie zastosował. Zapewne opisanie i przedstawienie na mapie podziałów etnograficznych według prototypowej koncepcji zróżnicowania etnograficznego byłoby trudniejsze, gdyż trzeba by było najpierw wskazać owe centralne miejsca rodowości oraz określić panujące tam wzorce charakterystyczne dla poszczególnych rodów, opisać różnice między nimi oraz występujące w danych „kółkach rodowych” stopnie odchylenia od prototypu itd. Pod tym względem odnaleźć można w pracach Pola jedynie pewne wskazówki. Uważał on, że „środkowym punktem zebrania dla rodów, były zawsze wyobrażenia religijne (...)" (Pol 1850: 20). Dlatego odniósł siedliska górali karpackich „do stosunków religijnych, które po zawiązaniu się węzłów rodowych na danym obszarze, zwykły tworzyć pierwszy punkt duchowego skupienia" (Pol 1851: 132). Ponadto sugerował, że „strój oddzielny” jest najbardziej uderzającym znamieniem danej rodowości. Przy czym, tak jak „wszystkie cechy rodowe, tak zmienia się i strój rodu w drobnych rzeczach od wsi do wsi prawie, ale są cechy wspólne całym okolicom połączonym węzłem jednej rodowości i te są istotne" (Pol 1966: 193). Owe istotne cechy, to sposób noszenia włosów, nakrycie lub ubranie głowy, obuwie, wierzchnia suknia, a przede wszystkim jej krój i kolory ulubione przez dany ród. „W barwie od pewnego rodu ulubionej wyraża się najżywiej uczucie jego, przechowuje się najdłużej podanie rodzinnego pochodzenia" (Pol 1966: 194). Poza tym indywidualność rodu wyraża się w poczuciu odrębności i nazwie, w miejscowym narzeczu, w tańcu oddzielnym, w sposobie życia i gospodarowania, i w ogóle w „pewnej cywilizacji miejscowej”, dzięki której zaspokajają wszystkie swoje życiowe potrzeby (Pol 1966: 185-189). 
Szersze przedstawienie tej ledwie naszkicowanej wyżej - inspirowanej niektórymi poglądami Pola - i jednej z kilku możliwych, a konkurencyjnych względem tradycyjnej teorii rozumienia etnograficznego zróżnicowania, wymaga oczywiście głębszych i szerszych studiów. Szczególnie interesujące byłoby w tym kontekście odwołanie się do kognitywistyki.

\section{Bibliografia}

Anczyc, W.L. (1874). Zakopane i lud podhalski. Tygodnik Ilustrowany, 341, 27-28.

Babicz, J. (1966). Wstęp: Uwagi nad materiałami do etnografii północnych stoków Karpat Wincentego Pola. W: W. Pol, Prace z etnografii północnych stoków Karpat (s.9-72). Wrocław: Polskie Towarzystwo Ludoznawcze.

Bogatyński, W. (1912). Nowotarszczyzna. Lud, 18, 58-78

Bredetzky, S. (1810). Reisebemerkungen über Ungarn und Galizien. Wien: Anton Doll.

Bujak, F. (1902). Przyczynek do kwestyi „Lachów” i „Górali”. Lud, 8, 161-168.

Bystroń, J.S. (1927). Nazwy i przezwiska polskich grup plemiennych i lokalnych. Prace i Materiały Antropologiczne, Archeologiczne i Etnograficzne, 4, 95-152.

Bystroń, J.S. (1939). Wstęp do ludoznawstwa polskiego. Warszawa-Poznań: Polski Instytut Socjologiczny

Bystroń, J.S. (1976). Dzieje obyczajów w dawnej Polsce: wiek XVI-XVIII. 1. Warszawa: Państwowy Instytut Wydawniczy

Cholewa, M. (1946). Stroje ludowe Ziemi Sądeckiej: rozwój stroju ludowego i jego zasięgi terytorialne. Lud, 36, 256-279.

Chwedeńczuk, B. (1984). Spór o naturę prawdy. Warszawa: Państwowy Instytut Wydawniczy.

Czechowicz, E. (1884). Geografia dla użytku szkół ludowych. Kołomyja: H. Zadembski, A. Hollender.

Delaveaux, L. (1851). Górale Beskidowi zachodniego pasma Karpat. Rys etnograficzny zwyczajów i obyczajów włościan okolic Żywca. Kraków: J. Czech.

Durkheim, E., Mauss, M. (1973). O niektórych pierwotnych formach klasyfikacji. Przyczynek do badań nad wyobrażeniami zbiorowymi. W: M. Mauss, Socjologia i antropologia (s. 707-802), (przeł. M. Król, K. Pomian, J. Szacki). Warszawa: Państwowe Wydawnictwo Naukowe.

Dynowska, I. (1995). Wody. W: J. Warszyńska (red.), Karpaty Polskie: przyroda, człowiek i jego działalność (s. 49-67). Kraków: Wydawnictwo Uniwersytetu Jagiellońskiego.

Eco, U. (2006). Sztuka i piękno w Średniowieczu (przeł. M. Kimula, M. Olszewski). Kraków: Wydawnictwo Znak.

Eljasz, W. (1874). Szkice z podróży w Tatry. Poznań: Tyg. Wielkopol.

Eljasz-Radzikowski, S. (1900). Lachy w Polsce i na Słowaczyźnie. Lud, 6, 301-303.

Fischer, A. (1926). Lud polski: podręcznik etnografji Polski. Lwów: Druk. Zakładu Narodowego im. Ossolińskich.

Flatt, O. (1859). Wspomnienie Tatrów. Księga Świata, 1, 104-114. Warszawa: S.H. Merzbach.

Frankowski, E. (1928). Lud Polski i jego kultura. W: Dziesięciolecie Polski Odrodzonej: księga pamiątkowa 1918-1928 (s. 31-42). Kraków-Warszawa: Ilustrowany Kuryer Codzienny, Światowid, Na szerokim Świecie.

Goszczyński, S. (1853). Dziennik podróży do Tatrów przez autora Sobótki. Petersburg: B.M. Wolff. 
Grabowski, A. (1909). Wspomnienia, 1. Kraków: Drukarnia Czasu.

Gustawicz, B. (1881). Galicya. W: F. Sulimierski. B. Chlebowski, W. Walewski (red.), Słownik geograficzny Królestwa Polskiego i innych krajów słowiańskich, 2, (s. 445-474). Warszawa: Drukarnia Wieku.

Hacquet, B. (1790-1796). Neueste physikalisch-politische Reisen in den Jahren 1788-1795 durch die Dacischen und Sarmatischen oder Nördlichen Karpathen. 1-4. Nürnberg: Verlag der Raspischen Buchhandlung.

Jakóbiec, J. (1901). Przyczynek do oznaczenia granicy Lachów. Lud, 7, 256-259.

Kamocki, J. (1965). Zarys grup etnograficznych w Polsce. Warszawa: Polskie Towarzystwo Turystyczne.

Kłodnicki, Z. (1995). Polskie grupy etnograficzne (zasięgi przybliżone). W: Ginące zawody. Program. Warszawa: Ministerstwo Kultury i Sztuki.

Konopka, J. (1874). Gospodarstwo górskie. W: J.T. Lubomirski, E. Stawiski, S. Przystański (red.), Encyklopedya rolnictwa i wiadomości związek z niem mających, 2, (s. 812-846). Warszawa: Gebethner i Wolff.

Kopczyńska-Jaworska, B. (1969). Tradycyjna gospodarka sezonowa w Karpatach Polskich. Wrocław: Ossolineum.

Kopernicki, I. (1877). Wskazówki dla robiących spostrzeżenia antropologiczne i etnologiczne w górach. Pamiętnik Towarzystwa Tatrzańskiego, 2, 109-113.

Kronbach, E. (1820). Darstellungen as dem Königreiche Galizien, insbesondere der Karpathen im Sandecer Kreise. Wien.

Kutrzeba-Pojnarowa, A. (1967). Ważniejsze terytoria i grupy etnograficzne. W: Wielka encyklopedia powszechna PWN, 9. Warszawa: Państwowe Wydawnictwo Naukowe.

Kutrzeba-Pojnarowa, A. (1977). Kultura ludowa i jej badacze: mit i rzeczywistość. Warszawa: Ludowa Spółdzielnia Wydawnicza.

Lutostański, B. (1874). Zarys planu prac Sekcji antropologicznej. Rozprawy i sprawozdania z posiedzeń WM-P AU, 190-209.

Łepkowski, J. (1852). Listy z podróży archeologicznej po Galicji: Jasielskie. W: A. Zieliński (red.), Romantyczne wędrówki po Galicji, (s. 311-324). Wrocław: Ossolineum.

Mauss, M.(1973). Fragment planu ogólnej socjologii opisowej. W: M. Mauss, Socjologia i antropologia (s.809-870), (przeł. M. Król, K. Pomian, J.Szacki). Warszawa: Państwowe Wydawnictwo Naukowe.

Mehoffer, J. (1843). Der Wadowizer-Kreis im Königreich Galizien. Wien.

Młynek, L. (1903). W sprawie „Lachów” (przyczynek). Lud, 9, 253-263.

Mundt, T. (1840). Völkerschau auf Reisen, 1. Stuttgard.

Nowakowski, F. (1858). Szczawnica w roku 1857. Gazeta Warszawska, 147.

Paryscy, Z. i W.H. (1995). Wielka Encyklopedia Tatrzańska. Poronin: Wydawnictwo Górskie.

Pol, W. (1847). Muzeum natury we Lwowie. Biblioteka Narodowego Zakładu imienia Ossolińskich, 1(4), 333-371; 1(5), 445-493.

Pol, W. (1851). Rzut oka na północne stoki Karpat i przyległe im krainy. Kraków: Drukarnia Czasu.

Pol, W. (1869). Obrazy z życia i natury, 1. Kraków: Drukarnia Uniwersytetu Jagiellońskiego.

Pol, W. (1870). Obrazy z życia i natury: Północny wschód Europy, 2. Kraków: Drukarnia Uniwersytetu Jagiellońskiego.

Pol, W. (1878). Historyczny obszar Polski. W: Dzieła prozą Wincentego Pola (s. 3-137). Lwów: nakładem F.H. Richtera. 
Pol, W. (1966). Prace z etnografii północnych stoków Karpat. Wrocław: Polskie Towarzystwo Ludoznawcze.

Reinfuss, R. (1946). Pogranicze krakowsko-góralskie w świetle dawnych i najnowszych badań etnograficznych. Lud, 36, 222-255.

Rohrer, J. (1804). Bemerkungen auf einer Reise von der Türkischen Gränze über die Bukowina durch Ost und West Galizien, Schlezien und Mähren nach Wien. Wien.

Schneider, A. (1871). Encyklopedya do krajoznawstwa Galicyi, 1. Lwów: Drukarnia Narodowego Zakładu imienia Ossolińskich.

Siarczyński, F. (1827). Słownik historyczno-statystyczno-geograficzny królestwa Galicyi: Wiadomości ogólne. 1. Rkp sygn. oryg. 1827/III.

Staszic, S. (1815). O ziemiorodztwie Karpatow i innych gor i równin Polski. Warszawa: Drukarnia Rządowa.

Szaflarski, J. (1972). Poznanie Tatr: Szkice z rozwoju wiedzy o Tatrach do połowy XIX wieku. Warszawa: Sport i Turystyka

Śniadecki, J. (1804). Jeografia czyli opisanie matematyczne i fizyczne ziemi. Warszawa: Drukarnia Xieży Piiarów.

Tatomir, Ł. (1874). Geografia Galicyi: podręcznik dla uczniów seminariów nauczycielskich i dla nauczycieli szkół ludowych. Lwów: K. Wild.

Udziela, S. (1918). Etnograficzne ugrupowanie i rozmieszczenie rodów Górali polskich. Przegląd Geograficzny, 1, 80-91.

Warszyńska, J. (1995). Wstęp. W: J. Warszyńska (red.), Karpaty Polskie. Przyroda, człowiek i jego działalność (s. 9-11). Kraków: Wydawnictwo Uniwersytetu Jagiellońskiego.

Węglarz, S. (1997). Tutejsi i inni. O etnograficznym zróżnicowaniu kultury ludowej. „Łódzkie Studia Etnograficzne", 36. Łódź: Polskie Towarzystwo Ludoznawcze.

Węglarz, S. (2010). Antropologia hermeneutyczna wobec tradycyjnych tekstów kulturowych: przykład interpretacji wyobrażeń naukowych o Tatrach i góralach tatrzańskich do połowy XIX wieku. Katowice: Wydawnictwo Uniwersytetu Śląskiego.

Węglarz, S. (2017). Górale jako dzieci natury. Studia Etnologiczne i Antropologiczne, 17, 70-85.

Wrześniowski, A. (1882). Tatry i Podhalanie. Pamiętnik Towarzystwa Tatrzańskiego, 7, 1-53.

X.S., [Serwatowski W.] (1851). Rys ethnograficzny Galicyi i Bukowiny. Czas, 36, 1; 37, 1-2.

Zawiliński, R. (1893). Przyczynek do etnografii górali polskich na Węgrzech. Zbiór Wiadomości do Antropologii Krajowej, 17, 1-13.

Zawiliński, R. (1896). Przyczynek II. Do etnografii górali polskich na Węgrzech. Materiały Antropologiczno-Archeologiczne i Etnograficzne, 1, 380-425.

Zejszner, L. (1844). Rzut oka na Podhalan. Biblioteka Warszawska, 3, 113-149.

Zejszner, L. (1848). Podróże po Bieskidach czyli opisanie gór Karpackich, zawartych pomiędzy źródłami Wisły i Sanu. Biblioteka Warszawska, 3, 96-145, 371-399, 476-531.

Zejszner, L. (1849). Podhale i północna pochyłość Tatrów czyli Tatry polskie. Biblioteka Warszawska,1, 57-91, 535-568; 3, 441-462; 4, 1-28.

Zejszner, L. (1850). Podróż do źródeł Wisły. Biblioteka Warszawska, 1, 421-441.

Zejszner, L. (1851). Podhalei północna pochyłość Tatrów czyli Tatry polskie. BibliotekaWarszawska, 4, 523-542.

Zejszner, L. (1852). Podhale i północna pochyłość Tatrów czyli Tatry polskie. BibliotekaWarszawska, 2,116-130

Zejszner, L. (1853). Orawa. Biblioteka Warszawska, 3, 319-341. 


\section{Spis ilustracji}

II.1. Granice karpackich grup etnicznych wg opracowania Józefa Babicza. Oprac. P. Rutkowski, 2021 r.

II.2. Góralszczyzna i jej wewnętrzne podziały. Oprac. P. Rutkowski, 2021r.

\section{Streszczenie}

Już w pierwszej połowie XIX wieku zaczęto podejmować próby opisania mieszkańców Karpat (Góralszczyzny karpackiej), z uwzględnieniem istniejących podziałów na grupy („rody”) czy regiony etnograficzne. Zgodnie z modernistycznym (oświeceniowo-pozytywistycznym) paradygmatem poznania naukowego ujmowano owe grupy/regiony na sposób „substancjalny”, kierując się przy tym zasadami naturalizmu przedmiotowego i metodologicznego. Pierwszym badaczem, który dokonał podziału ludności zamieszkującej północne stoki Karpat - analogicznie do tego, jak się te góry dzielą - na trzy „grupy etnograficzne”, a w nich na „rody”, był Wincenty Pol. Tej dosyć szczegółowej delimitacji etnograficznej nie przedstawił w formie graficznej, ze względu na brak odpowiedniej do tego celu mapy. Szczegółową mapę, prezentującą dokonane przez Pola i kilku innych badaczy podziały oraz zasięgi polskiej Góralszczyzny i wchodzących w jej skład grup etnograficznych, wykonał dopiero prawie 120 lat później Józef Babicz. Różnice pomiędzy wytyczanymi przez różnych uczonych granicami Góralszczyzny i zasięgami wchodzących w jej skład grup/regionów wskazują, że substancjalne ujęcie tych zagadnień jest nieadekwatne do obrazowanej rzeczywistości społecznej i kulturowej. Pewne poglądy Pola mogą być inspiracją dla stworzenia alternatywnej koncepcji zróżnicowania etnograficznego w ogóle, a polskiej Góralszczyzny w szczególności.

Słowa klucze: Góralszczyzna, etnografia, mapy, substancjalizm, prototyp

\section{Summary}

As early as the first half of the 19th century, attempts were made to describe the inhabitants of the Carpathians (Carpathian Highlander Region - Góralszczyzna), taking into account the existing divisions into groups ("clans") or ethnographic regions. In accordance with the modernist (Enlightenment-positivist) paradigm of scientific cognition, these groups / regions were presented in a "substantial" manner, following the principles of the objective and methodological naturalism. The first researcher who divided the population living in the northern slopes of the Carpathians - analogically to how these mountains are divided - into three "ethnographic groups" and in then into "clans" was Wincenty Pol. He did not present this quite detailed ethnographic delimitation in a graphic form due to the lack of a map suitable for this purpose. A detailed map, presenting the divisions and ranges of the Polish Highlander Region and its ethnographic groups proposed by Pol and several other researchers, was made only almost 120 years later by Józef Babicz. The differences between the boundaries of the Highlander region and the ranges of the groups / regions it contains indicate that the substantial approach to these issues is inadequate to the depicted social and cultural reality. Certain views of Pol may inspire the creation of an alternative concept of ethnographic diversity in general, and of the Polish Highlander Region in particular.

Keywords: Highlander region, ethnography, maps, substantialism, prototype 